\title{
A Study on Distribution of Cancer Cases Diagnosed in Çorum
}

\section{Çorum Illinde Tanı Konulan Kanser Olgularının Dağııımı Üzerine Bir Çalışma}

\author{
YıImaz BAŞ, Pınar UZBAY, Güven GÜNEY, Behice Hande ERENLER, Dilek YILMAZ, Çiğdem ÖZDEMiR
}

Department of Pathology, Hitit University, Çorum Education and Research Hospital, ÇORUM, TURKEY

\begin{abstract}
Objective: In order to help obtain accurate knowledge and to contribute to the establishment of data for regional tumor statistics, we aimed to determine the frequency distribution of cancer cases that was diagnosed in Çorum province.

Material and Method: In this descriptive study, we retrospectively reviewed the archive records of the pathology departments' of one university hospital and two private hospitals serving in the province of Çorum. A total of 138,973 recorded pathology reports were reviewed. Metastatic cancers with a known primary source were excluded. A total of 2184 cases with a diagnosis of cancer were recorded by gender, age, and system/organ and classified to 10 most frequent types of cancer both in general and in terms of gender distribution.
\end{abstract}

Results: The male to female ratio was 1.44 and the mean age was 64.26 years. The cancer is most commonly encountered between 70 and 79 years of age (35.27\%) in males whereas the second most common interval was 60 to 69 years of age (23.88\%). In females, the cancer is most commonly encountered between 70 and 79 years of age $(24.16 \%)$ whereas the second most common interval was 60 to 69 years of age $(22.60 \%)$. The top five cancers were skin $(33.60 \%)$, prostate $(13.87 \%)$, stomach $(9.07 \%)$, urinary bladder $(8.61 \%)$ and breast $(7.88 \%)$.

Conclusion: Distribution of organ/system involvement of cancer cases that were diagnosed in Çorum is quite different from the data regarding Turkey in general. Development of cancer registry centers, upgrading to an active registry system and having all cancer data from health institutions unified in a single organization are mandatory to achieve reliable data.

Key Words: Epidemiology, Cancer, Turkey

\section{ÖZ}

Amaç: Çorum ilinde bölgesel tümör istatistiklerinin oluşturulmasına katkıda bulunacak güvenilir bilgiler sağlamak amacıyla bu ilde tanı konulan kanser olgularının yaş, cinsiyet ve organ dağılım frekanslarını belirlemeyi amaçladık.

Gereç ve Yöntem: $\mathrm{Bu}$ tanımlayıcı retrospektif çalışmada Çorum ilinde hizmet veren bir üniversite hastanesi ve iki özel hastanenin patoloji bölümlerinin arşiv kayıtları incelendi. Toplam 138.973 kayıtlı patoloji raporu tarandı. Primer odakları bilinen metastatik kanserler çalışma dışı tutuldu. Kanser tanısı alan toplam 2184 olgunun en sık görülen 10 kanser tipine göre cinsiyet, yaş ve sistem/organ dă̆ılımları belirlendi.

Bulgular: Erkek/kadın oranı 1.44 olup ortalama yaş 64.26 yıldı. Kanser erkeklerde en sık 70-79 yaş aralığında $(\% 35,27)$ görülmekteyken ikinci en sık aralık 60-69 yaş aralığıydı $(\% 23,88)$. Kanser kadınlarda en sık 70-79 yaş aralığında $(\% 24,16)$ görülmekteyken, ikinci en sık aralık 60-69 yaş aralığıydı (\%22,60). En sık görülen ilk beş kanser sirasiyla cilt $(\% 33,60)$, prostat $(\% 13,87)$, mide $(\% 9,07)$, mesane $(\% 8,61)$ ve meme kanseriydi $(\% 7,88)$.

Sonuç: Çorum ilinde tanı konulan kanser olgularının organ/sistem dağılımı Türkiye genelindeki verilerden farklıdır. Güvenilir verilerin elde edilebilmesi için kanser kayıt merkezlerinin gelişimi, aktif kanser kayıt sistemine geçilmesi ve tüm sağlık kuruluşlarından elde edilecek kanser verilerinin tek bir organizasyon altında birleştirilmesi gereklidir.

Anahtar Sözcükler: Epidemiyoloji, Kanser, Türkiye

\section{INTRODUCTION}

Cancer is the leading cause of death in developed countries whereas it is the second leading cause of death in developing countries, where heart disease is still the leading cause (1). According to the 2010 data from World Health

(Turk Patoloji Derg 2014, 30:118-123)

Received : 19.11.2013 Accepted : 02.04.2014
Organization, there are 12.4 million new cases of cancer, 25 million patients with cancer and 7.6 million cancer deaths throughout the world (2). The world has been divided into 22 regions (top 22 cancer site) by the incidence and the rate of mortality. Turkey was included in the West Asia region with the code number 13 (3). In Turkey, cardiovascular

Correspondence: Yılmaz BAŞ

Hitit Üniversitesi, Çorum Eğitim ve Araştırma Hastanesi, Patoloji Bölümü, CORUM, TURKEY

E-mail: yilbas@yahoo.com Phone: +90 3642230300 
diseases are the first leading cause of death whereas cancer is the second leading cause (15.4\%) (4). According to the Turkey's 2013 Health Statistics Yearbook from Ministry of Health, the incidence of cancer was reported to be 281.6 cases per 100.000 people (5).

The fact that data from pathology departments is constantly being recorded and also that the science of pathology had a substantial growth in the global scale have contributed to the construction of a substantial database of cancer records. The previous studies that were performed in our country during the last three decades tried to reveal the distribution of malignant tumors by geographical, gender and organs involved (6-19). A recent study reported that age and sex adjusted crude death rate of cancer in Çorum was 21.92 (20), however, there has not yet been any report regarding the frequency and distribution of cancer subtypes in this province.

The present study aimed to determine the frequency distribution of cancer cases by age groups, gender and organ location in Çorum. We also aimed to help obtain accurate knowledge that would be useful when conducting future studies and also to contribute to the establishment of data for regional tumor statistics.

\section{MATERIAL and METHODS}

We conducted a retrospective descriptive study on organ/ system distribution of cancer cases diagnosed in Çorum. A particular permission was granted from the ethics committee of Numune Education and Research Hospital to review the pathology archive records of the Department of Pathology, Hitit University Çorum Education and Research Hospital and two private hospitals serving in the province of Çorum (30.01.2014/ 724.112). Other than these three departments, there is no other pathology department in Çorum and there has not been any other facility that receives specimens for histopathological examination. Histopathological reports were included in data analysis if there was no suspicion about the diagnosis. Reports were not included if they indicated that the sampling material was inappropriate or there was need for repeating the sample taking. Histopathological examination reports of 113.685 sampling materials (obtained by excision, resection, punching, needle biopsy and body fluid evacuation) that were examined between 01.01.2006 and 30.05.2013 in Department of Pathology, Hitit University Çorum Education and Research Hospital were reviewed both from the department's archive records and from the computerized records using a specialized data automation database which has been established in 2007. 5343 biopsy examination reports obtained between 01.11.2011 and 30.05.2013 in one private hospital and 19945 biopsy examination reports obtained between 01.01.2010 and 30.05.2013 in the other private hospital were individually reviewed using the computer software that uses a specific database. Thus, a total of 138,973 recorded pathology reports were retrospectively reviewed. If there was more than one organ biopsy belonging to the same individual patient, among them, the one which best represented the diagnosis was taken into consideration. If there were different organ biopsies in the same patient, these different organ biopsies were included in the study. The patients who had a diagnosis of metastatic cancer with a known primary source were excluded. Data from the patients who were under 16 years old were not included. A total of 2184 cases in whom the diagnosis of cancer were made in Çorum were recorded by gender, age, and system/organ and classified to 10 most frequent types of cancer both in general and in terms of gender distribution.

\section{RESULTS}

Distribution of all cancer cases by organ, system and gender was shown in Table I. Among the whole study group, the top five cancers were; skin (33.60\%), prostate (13.87\%), stomach (9.07\%), urinary bladder (8.61\%) and breast (7.88\%) (Table I). Among the females (Table II), cancers of skin (38.37), breast (\%19.24), thyroid (\%12.64), colorectal (\%7.83) and stomach (\%5.48) were the top five cancers whereas cancers of skin (\%30.31), prostate (\%23.49), urinary bladder (12.95), stomach (\%11.55) and colorectal (\%5.58) were the top five among males (Table III). Out of 2184 cases with a diagnosis of cancer, 1290 were males (59.06\%) and 894 were females (40.94\%). The male to female ratio was 1.44 . The youngest patient was 17 years old, the oldest one was 96 years old and the mean age was 64.26 years.

There were 415 patients (19\%) under 50 years of age and 1769 (81\%) patients over 50 years of age. The frequency peaks between 70 and 79 years of age in males and females. Cancer was most commonly encountered between 70 and 79 years of age $(35.27 \%)$ in males whereas the second most common interval was 60 to 69 years of age (23.88\%). In females, cancer was most commonly encountered between 70 and 79 years of age (24.16) whereas the second most common interval was 60 to 69 years of age (22.60) (Figure 1).

According to the systems involved, the skin at $33.31 \%$, gastrointestinal system at $18.45 \%$, male genital system at $14.65 \%$, urinary system at $9.57 \%$ and breast at $7.88 \%$ were the top five systems. Among the skin cancers, the 
Table I: Organ/system and gender distribution of the study group

\begin{tabular}{|c|c|c|c|c|c|c|c|}
\hline $\begin{array}{c}\text { Frequency } \\
\text { order }\end{array}$ & Organ/System & $\begin{array}{c}\text { Total } \\
\text { number }\end{array}$ & $\begin{array}{c}\text { Total } \\
\text { percentage }\end{array}$ & $\begin{array}{c}\text { Number of } \\
\text { males }\end{array}$ & Percentage & $\begin{array}{c}\text { Number } \\
\text { of females }\end{array}$ & Percentage \\
\hline 1 & Skin & 734 & 33.60 & 391 & 30.31 & 343 & 38.37 \\
\hline 2 & Prostate & 303 & 13.87 & 303 & 23.49 & - & - \\
\hline 3 & Stomach & 198 & 9.07 & 149 & 11.55 & 49 & 5.48 \\
\hline 4 & Urinary Bladder & 188 & 8.61 & 167 & 12.95 & 21 & 2.35 \\
\hline 5 & Breast & 172 & 7.88 & - & - & 172 & 19.24 \\
\hline 6 & Colorectal & 142 & 6.50 & 72 & 5.58 & 70 & 7.83 \\
\hline 7 & Thyroid & 122 & 5.59 & 9 & 0.70 & 113 & 12.64 \\
\hline 8 & Lung & 43 & 1.97 & 40 & 3.10 & 3 & 0.34 \\
\hline 9 & Oral Cavity (Lip Included) & 41 & 1.88 & 33 & 2.56 & 8 & 1.89 \\
\hline 10 & Uterine Corpus & 40 & 1.83 & - & - & 40 & 4.47 \\
\hline 11 & Soft Tissue Sarcomas & 31 & 1.42 & 21 & 1.63 & 10 & 1.12 \\
\hline 12 & Gall Bladder & 23 & 1.05 & 7 & 0.54 & 16 & 1.79 \\
\hline 13 & Kidney & 21 & 0.96 & 13 & 1.01 & 8 & 1.89 \\
\hline 14 & Esophagus & 20 & 0.92 & 16 & 1.24 & 4 & 0.45 \\
\hline 15 & Testicular & 17 & 0.78 & 17 & 1.32 & - & - \\
\hline 16 & Non-Hodgkin Lymphoma & 17 & 0.78 & 12 & 0.93 & 5 & 0.57 \\
\hline 17 & Nasopharynx & 14 & 0.64 & 11 & 0.85 & 3 & 0.34 \\
\hline 18 & Bone Metastasis & 11 & 0.50 & 5 & 0.39 & 6 & 0.67 \\
\hline 19 & Uterine Cervix & 10 & 0.46 & - & - & 10 & 1.12 \\
\hline 20 & Pleural/Pericardial Fluid $*$ & 8 & 0.37 & 5 & 0.39 & 3 & 0.34 \\
\hline 21 & Larynx & 7 & 0.32 & 7 & 0.54 & - & - \\
\hline 22 & Ovary & 6 & 0.27 & - & - & 6 & 0.67 \\
\hline 23 & Peritoneum/Omentum & 6 & 0.27 & 4 & 0.31 & 2 & 0.22 \\
\hline 24 & Hodgkin'symphoma & 3 & 0.14 & 3 & 0.23 & - & - \\
\hline 25 & Brain & 3 & 0.14 & 3 & 0.23 & - & - \\
\hline 26 & Liver & 2 & 0.09 & - & - & 2 & 0.22 \\
\hline 27 & Small Intestine & 2 & 0.09 & 2 & 0.16 & - & - \\
\hline Total (n) & & $\mathbf{2 1 8 4}$ & & $\mathbf{1 2 9 0}$ & $\mathbf{5 9 . 0 6}$ & $\mathbf{8 9 4}$ & $\mathbf{4 0 . 9 4}$ \\
\hline
\end{tabular}

* Source unknown, registry duplication avoided

Table II: Organ/system distribution of the ten most frequent cancers among women

\begin{tabular}{|l|c|c|c|}
\hline No & Location & $\begin{array}{c}\text { Number of } \\
\text { women (n) }\end{array}$ & Percentage \\
\hline 1 & Skin & 343 & 38.4 \\
\hline 2 & Breast & 172 & 19.2 \\
\hline 3 & Thyroid & 113 & 12.6 \\
\hline 4 & Colorectal & 70 & 7.83 \\
\hline 5 & Stomach & 49 & 5.48 \\
\hline 6 & Uterine Corpus & 40 & 4.47 \\
\hline 7 & Urinary Bladder & 21 & 2.35 \\
\hline 8 & Gall Bladder & 16 & 1.79 \\
\hline 9 & Soft Tissue Sarcomas & 10 & 1.12 \\
\hline 10 & Uterine Cervix & 10 & 1.12 \\
\hline
\end{tabular}

Table III: Organ/system distribution of the ten most frequent cancers among men

\begin{tabular}{|l|c|c|c|}
\hline No & Location & $\begin{array}{c}\text { Number of } \\
\text { men (n) }\end{array}$ & Percentage \\
\hline 1 & Skin & 391 & 30.31 \\
\hline 2 & Prostate & 303 & 23.49 \\
\hline 3 & Urinary Bladder & 167 & 12.95 \\
\hline 4 & Stomach & 149 & 11.55 \\
\hline 5 & Colorectal & 72 & 5.58 \\
\hline 6 & Lung & 40 & 3.1 \\
\hline 7 & Oral Cavity (Lip Included) & 33 & 2.56 \\
\hline 8 & Soft tissue Sarcomas & 21 & 1.63 \\
\hline 9 & Testicular & 17 & 1.32 \\
\hline 10 & Esophagus & 16 & 1.24 \\
\hline
\end{tabular}




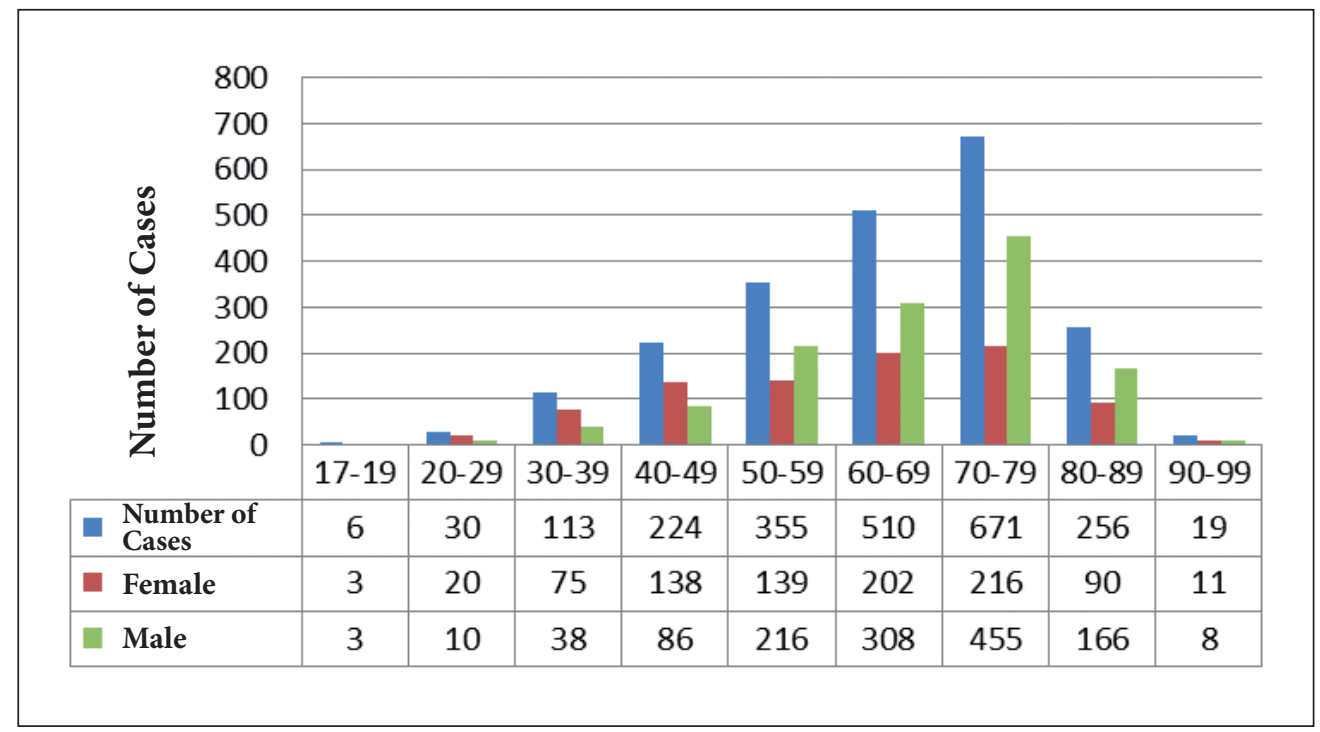

Figure 1: Male-female distribution of cases by age groups. patients with the diagnosis of basal cell carcinoma (521 cases, 70.98\%) comprised the highest number of cases. The squamous cell carcinoma (172 cases, $23.43 \%$ ) and the malignant melanoma (23 cases, $3.13 \%$ ) were the second and third most frequently diagnosed cancers, respectively.

\section{DISCUSSION}

This was a retrospective descriptive study in design and reflects the latest frequency of cancer cases diagnosed in Çorum. Distribution of organ/system involvement of cancer cases that were diagnosed in Çorum is quite different from the data regarding our country. The incidence rate of lung cancer ranks first among males in Turkey whereas, in our study, lung cancer ranked $6^{\text {th }}$ with $1.97 \%$ among the study group, ranked $6^{\text {th }}$ with $3.10 \%$ among men and ranked lower with $0.34 \%$ among women. The uterine corpus cancer is the fourth most frequently diagnosed cancer among women in Turkey whereas it is the $5^{\text {th }}$ most frequently diagnosed cancer in our series after the skin cancers were excluded (21). Inconsistency in ranking of lung and uterus cancers is misleading. The fact that it is common predilection to apply to the superior hospitals in Samsun and Ankara which are relatively closer to the Çorum province due to its geographical location and also that health services remain limited in Çorum province may possibly be main causes of this inconsistency.

The establishment of cancer registry systems is of importance for etiologic causes to be revealed, necessary interventions to be made for cancer prevention and for "cancer biology" studies to be developed and controlled. The previous studies that were performed in our country during the last three decades tried to reveal the distribution of malignant tumors by geographical, gender and organs involved (6-19).

Cancer cases have been included to the list "notifiable diseases" since 1982. The first population based cancer registry system was established in 1992 in İzmir and Diyarbakur. In our country, there has been 11 active Cancer Registry Centers that collect the data through this system since 2010. These provinces are Ankara, İzmir, Antalya, Samsun, Eskişehir, Erzurum, Edirne, Trabzon, Gaziantep, Malatya and Bursa (4). According to the 2013 data from the Cancer Department in the Ministry of Health of Turkey, the most common types and their incidence rates among women are as follows; breast (40.7), thyroid (16.2), colorectal (13.2), corpus uteri (8.6) and lung (8.2), whereas those among men are as follows; lung (69.2), prostate (37.6), urinary bladder (21.7), colorectal (20.8) stomach (18.0) (21).

In our study, skin cancer is the most common tumor among men and women. Early diagnosis on skin surface is very easy to make. Also, because the skin surface can easily be visualized, there is no need for superior hospital standards for surgical procedures. Our results are similar to those reported by others in our country (6-10). This high frequency may be related with the ease of the early diagnosis and may also result from the prolonged exposure to sunlight and the depletion of the ozone layer, as well.

In our study, breast cancer is the second most frequently diagnosed cancer among women. When the cases with skin cancer were excluded, breast cancer is the most frequently diagnosed cancer with $31.21 \%$ and this result is similar with the literature. The breast cancer was also the most 
frequently diagnosed cancer in series reported by some others $(9,11-16)$. The studies reported by Tasdemir (11), Basak (6), Kandiloglu (17) and Ozekinci (8) are similar to ours where breast cancers are the second most frequently diagnosed cancers after skin cancers.

In our study, thyroid cancer which mainly affects women was found in $0.70 \%(n=9)$ of men whereas it was the third most frequently diagnosed cancer with $12.64 \%(n=113)$ among women. This finding is similar to that in the literature and to the data from the Cancer Department of Turkey (21). The incidence is being reported as 3-5.5/100.000 among women and 0.5-2/100.000 among men in the literature (22). Our findings are similar to those reported by others (6, 11,14 , and 18). It is the second most frequently diagnosed cancer in series of Bozkurt (7), fourth in series of Özekinci (8) and fifth in series of Bayram (19). The doubt that the radioactive cloud which formed as a result of a nuclear accident occurred in a neighboring country in the mid1980s might also have influenced our region has given rise to many speculations about increasing number of cancer cases. It is known that radioactivity acts as an etiological factor especially in thyroid carcinomas (23). Although thyroid cancer was approximately the $10^{\text {th }}$ most common type in Black Sea Region until 1990, it has risen to top ranks in recent years (22). The improvement of the imaging technologies for the thyroid gland and the high sensitivity of the clinic-radiologic and pathologic needle aspiration are of importance in the early detection of thyroid cancers.

In our study, colorectal cancer was the fourth and fifth most frequently diagnosed cancer in both women and among men. According to the data from the US, colorectal cancer is the second and third most frequently diagnosed cancer among women and men respectively, whereas it is the third most common cancer following breast and thyroid cancers among women and the fourth most common cancer after lung, prostate and urinary bladder cancers among men (3). Our study results are similar to the series of some others $(9,10,12)$. Early detection of adenomatous polyps by endoscopic methods and their removal is the key for the prevention of colorectal cancers. The simple screening tests such as occult blood test, barium imaging and colonoscopy (which is the "gold standard" due to its high sensitivity) are among the methods of importance in early diagnosis.

The stomach incidence and mortality have decreased in many parts of the world and all over Europe (3). It was the third most frequently diagnosed cancer among our study group and was the fifth and fourth most frequently diagnosed cancer among women and men, respectively. The increasing consumption of fresh food, vegetables and fruits, avoidance from ingestion of salt and convenience food, eradication of $\mathrm{H}$. pylori, reduction in smoking in developed areas, endoscopic screening methods and use of photofluorography in Japan are among the leading causes of the decrease observed in the incidence of stomach cancer (3).

The prostate cancer is the most frequently diagnosed cancer when the skin cancer was excluded. The data from the Department of Cancer reveal that the prostate cancer is the second most common cancer after lung cancer and this data is consistent with our study. Although the series reported by Arica (9) has similar findings to that of ours, we found unlikely that the urinary bladder cancers were the third most frequently diagnosed cancers after prostate cancers in our study. The prostate cancer is the fifth most frequently diagnosed cancer in series reported by Çolak (14) and Basak (6). We think that widespread use of the prostate specific antigen (PSA) test helped to achieve significant results in early diagnosing.

In our study, urinary bladder cancer was the third most frequently diagnosed cancer among men. It was detected in a minority of women. Our finding that urinary bladder cancer is four times more common among men than women is consistent with data from Turkey (24). Unlike the developed countries, urinary bladder cancer gradually increases in incidence in developing countries. Urinary bladder cancer was the second most frequently diagnosed cancer among men in the series reported by Arica (9) and was the third most frequently diagnosed cancer in those reported by Basak (6) and Çolak (14).

In conclusion, data from 3 pathology laboratories were analyzed in our study. The high rate of thyroid cancer among women is consistent with the literature and this finding may be explained by the fact that Çorum province located in Black Sea Region and it has a specific geological landform. "The ease of the early diagnosis" is of importance in these results. The low frequency of the diagnosis frequency of lung cancer is misleading and this may be explained by the patients' predilection to apply to the superior hospitals in Ankara. Similarly, eight patients in this study had positive histopathological findings in pericardial/pleural fluid samples and 11 patients had bone metastasis. However, no other registry was found regarding these patients. These findings do not truly indicate that these patients had primary neoplastic involvement in pericardial/ pleural or bone tissues. Therefore, efforts should be made for further development of an active cancer registry system. In addition, paving the way for the development of the pathology department within the context of molecular scale, 
establishing the radiation oncology department and further improvement of medical and surgical oncology specialties will help achieving significant results in improvement of diagnosis and treatment stages of cancer and in decreasing its mortality. It may be ascertained that it could be achieved in our country as well, to obtain more reliable data if the development of a widespread cancer registry system is undertaken.

As there is no active cancer registry database and we lack information on the total number of "population at risk", this report did not provide information about cancer incidence and prevalence in Çorum city.

\section{REFERENCES}

1. Mathers C, Fat DM, Boerma JT. The global burden of disease: 2004 update. Geneva, Switzerland: World Health Organization; 2008.

2. Ferlay J, Shin, HR, Bray F, Forman D, Mathers C, Parkin DM. GLOBOCAN 2008, cancer incidence and mortality worldwide: IARC CancerBase No. 10. Lyon International Agency for Research on Cancer; 2010. 29.

3. Jemal A, Bray F, Center MM, Ferlay J, Ward E, Forman D. Global Cancer Statistics. CA Cancer J Clin. 2011;61:69-90.

4. Türkiye'de Kanser Kayıtçılığı. Ankara: TC Sağlık Bakanlığı Kanserle Savaş Dairesi Başkanlı̆̆1; 2011. 1-29.

5. TC Sağlık Bakanlığı Sağlık İstatistikleri Yıllığı, available at: http:// www.saglik.gov.tr/TR/dosya/1-87578/h/istaturk2012.pdf

6. Başak K, Aksoy F. Ankara Numune Hastanesi’inde 1984-1992 Yılları Arasındaki Kanser Dağılımının Değerlendirilmesi. Ankara Patoloji Bulteni. 1993;10:62-71.

7. Bozkurt K, Bektaş SS, Doğru N. Şırnak ilinin kanser istatistikleri. Turk Patoloji Derg. 2011;27:230-4.

8. Özekinci S. Patoloji arşivindeki 10 ylllı kanser (19912000) olgularının genel değerlendirilmesi. Dicle Tip Dergisi. 2007;34:164-9.

9. Arıca S, Nazlıcan E, Özer C, Şilfeler DB, Arıca V, Özgür T, Özaydın Ü. Hatay ilinde 2008 yılı kanser vakaları sıklığı ve dağılımı. Klinik ve Deneysel Araştırmalar Dergisi. 2011;2:192-5.

10. Aydın Ö, Polat A, Düşmez D, Eğilmez R. Mersin ilinde kanser sıklığı ve dağılımı üzerine bir çalışma. Turk Patoloji Derg. 2000;16:48-50.

11. Taşdemir E, Demir C, Dilek İ, Atmaca M. Van ili ve çevresinde malign tümörlerin dă̆ılım sıklığı. Van Tıp Dergisi. 2010;17:114-7.
12. Haydaroğlu A, Bölükbaşı Y, Özsaran Z. Ege Üniversitesi'inde kanser kayıt analizleri: 34134 olgunun değerlendirilmesi. Turk Onkoloji Dergisi. 2007;22:22-8.

13. Alıcı S, İzmirli M, Doğan E. Yüzüncü Yıl Üniversitesi Tip Fakültesi Tıbbi Onkoloji Bilim Dalına başvuran kanser hastalarının epidemiyolojik değerlendirmesi. Turk Onkoloji Dergisi. 2006;21: 87-97.

14. Çolak HE, Yomralığlu T. Kanser Vakalarının Coğrafi Bilgi Sistemleri ile İrdelenmesi: Trabzon Örneği. HKM Jeodezi Jeoinformasyon ve Arazi Yönetimi Dergisi. 2007;96:39-47

15. Ecirli Ş, Borazan A, Tek B, Deveci A, Polat H. Selçuk Üniversitesi Tip Fakültesi Eğitim ve Araştırma Hastanesine 1993-99 yılları arasında kabul edilen erişkin kanser vakalarının değerlendirilmesi. Turkiye Klinikleri Journal of Medical Sciences. 2002;22:349-53.

16. Kılıç S, Kömürcü Ş, Rzayev M, Özet A, Kır T, Arpacı F. GATA Tıbbi Onkoloji Bilim Dalında izlenen hastaların bazı sosyodemografik özellikleri ve tanıları. Gulhane Medical Journal. 2004;46:115-24.

17. Kandiloğlu AR, Postacı H. SSK Buca Eğitim Hastanesi Patoloji Bölümünde İncelenen Materyal İçerisinde Kanser Sıklığı ve Dağılımı Son İki Yılda İncelenen 30671 Materyalin Değerlendirilmesi. Ankara Patoloji Bulteni. 1995;12:74-8.

18. İzmirli M, Altın S, Dernek BO, Ünsal M. SSK Okmeydanı Eğitim ve Araştırma Hastanesi Onkoloji Merkezi’nin 1999-2004 yılları kanser istatikleri. Turk Onkoloji Dergisi. 2007;22:172-82.

19. Bayram İ, Reçber D, İbiloğlu İ, Uğraş S. Bir patoloji anabilim dalında kanser sıklığı ve dağılımı. Ege Tıp Dergisi. 2005;44:21-7.

20. Koç H, Cengiz MA, Savaş N. Kanser ölüm hızının haritalandırılması: Türkiye için kesitsel bir çalışma örneği. Mapping of cancermortality rate: Crosssectionalstudy of Turkey. Fen Bilimleri Enstitüsü Dergisi. 2011;4:197-210.

21. Türkiye Halk Sağlığı Kurumu, Kanser Daire Başkanlığı, Kanser istatistikleri available at. http://www.kanser.gov.tr/dairefaaliyetleri/kanser-istatistikleri.html

22. Karagöz F, Yıldız L, Barış S, Özdamar Ş, Bakırtaş M, Aydın O. Ondokuzmayıs Üniversitesi Tip Fakültesi 1991-1996 yılları tiroid kanser istatistikleri. Ondokuzmayis Universitesi Tip Derg. 1998;15:324-9.

23. Lechago J, Gould VE. Bloodworth's endocrine pathology. 3 ed. Baltimore: Williams \&Wilkins; 1997;195-7.

24. Eser S, Özdemir R. Dünya ve Türkiye’de mesane kanseri epidemiyolojisi. Uroonkoloji Bulteni. 2012;11:1-9. 